\title{
Studies in molecular structure, symmetry and conformation
}

\author{
III. CRYSTAL AND MOLECULAR STRUCTURE OF 1-AMINO \\ CYCLOHEXANE CARBOXYLIC ACID HYDROCHLORIDE* \\ K. K. Chacko and R. SRInivasan \\ Centre of Advanced Study in Physics \\ University of Madras, Madras-25, India \\ AND \\ R. ZAND \\ Biophysics Research Division \\ University of Michigan, Ann Arbor, U.S.A.
}

(Received 7 September 1970)

\begin{abstract}
1-aminocyclohexane carboxylic acid hydrochloride crystallizes in the monoclinic space group $P 2_{1}$ with unit cell dimensions $a=9 \cdot 36, b=6 \cdot 40, c=7 \cdot 40 \AA$ and $\beta=96 \cdot 0^{\circ}$. The structure has been solved by beta synthesis and refined three-dimensionally to an $R$ factor of $10.9 \%$ with 817 observed reflexions. The conformation of the cyclohexane ring is a slightly distorted chair.
\end{abstract}

\section{Introduction}

In the earlier parts of this series, the crystal and molecular structures of 1-aminocyclooctane carboxylic acid hydrobromide (Srikrishnan, Srinivasan \& Zand, 1971) and 1-aminocycloheptane carboxylic acid hydrobromide monohydrate (Chacko, Srinivasan \& Zand, 1971) were reported. In this paper, we present the structure determination of 1-aminocyclohexane carboxylic acid hydrochloride, the chemical formula of which is given below.<smiles>NC1(C(=O)O)CCCCC1</smiles>

\section{Experimental}

Rotation, Weissenberg and precession photographs were taken with $\mathrm{Cu} K \alpha$ radiation $(\lambda=1.5418 \AA)$. The unit cell dimensions, calculated from precession photographs, and other crystal data are given below:

$\begin{array}{ll}\text { Crystal system } & \text { monoclinic } \\ \text { Unit cell dimensions } & a=9 \cdot 36 \pm 0 \cdot 01 \AA \\ & b=6 \cdot 40 \pm 0.01 \\ & c=7 \cdot 40 \pm 0 \cdot 01 \\ & \beta=96 \cdot 0 \pm 0 \cdot 5^{\circ}\end{array}$

* Contribution No. 315 from the Centre of Advanced Study in Physics, University of Madras, Madras-25, India. 


Systematic absences
Space group
Molecular formula
$Z$
$D_{m}$
$D_{c}$
$\mu(\mathrm{Cu} K \alpha)$

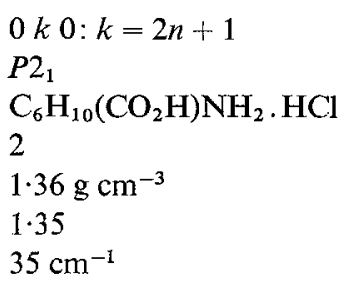

The centrosymmetric space group $P 2_{1} / m$ is unlikely for this crystal since the molecule could not be expected to have any symmetry; the noncentrosymmetric space group $P 2_{1}$ was assumed and was later confirmed by the successful structure analysis. A crystal of dimensions $0.045 \times 0.025 \times$ $0.020 \mathrm{~cm}^{3}$ was used for data collection. The intensity data were collected about the needle axis $b$ for $h k l, k$ going from 0 to 5 . A crystal of dimensions $0.035 \times 0.020 \times 0.030 \mathrm{~cm}^{3}$ was cut and used for collecting data for $h k l$ layers, $l$ going from 0 to 5 . The equi-inclination Weissenberg method was used for data collection. The intensities were estimated with a graded set of intensities obtained from one of the crystals. Lorentz, polarization and spot shape corrections (Phillips, 1962) were applied to the intensities. Corrections for absorption were not applied as $\mu r$ for the crystals used for the $b$ and $c$ axis data had the small values 0.39 and 0.44 respectively. The two sets of data were initially placed on an absolute scale by applying Wilson's method to individual layers.

\section{Structure determination and refinement}

A total of 767 reflexions were collected about the unique axis $b$ and used in an unsharpened Patterson synthesis from which the coordinates of the chlorine atoms were deduced. A chlorine-phased Fourier synthesis was performed for the location of the light atoms. The actual synthesis performed was a weighted beta synthesis (Ramachandran \& Raman, 1959). The weighting function was the squared form, in which the Fourier coefficients were multiplied by $W^{2}$ (Ramachandran \& Ayyar, 1963). The weight $W$ is given by

$$
W=I_{1}(2 X) / I_{o}(2 X)
$$

where

$$
X=\left|F_{o}\right|\left|F_{\mathrm{Cl}}\right| / \sum_{j} f_{j}^{2}
$$

and $I_{0}(2 x)$ and $I_{1}(2 x)$ are the modified Bessel functions of orders zero and one respectively. A composite diagram of the result of the beta synthesis is illustrated in Fig. 1. Since the space group is $P 2_{1}$ and the choice of origin along $y$ axis is arbitrary, the $y$ coordinates of the chlorine atoms were fixed at $y= \pm 0 \cdot 25$. There is necessarily a centre of inversion for two chlorine atoms alone in the unit cell, at the centre of the line joining them; consequently, the resultant map has a spurious mirror plane at $y=0.25$. However, the location of the light atoms was made easy because of the fact that the atoms $\mathrm{C}(1), \mathrm{C}(7), \mathrm{O}(1), \mathrm{O}(2), \mathrm{N}$ and $\mathrm{C}(4)$ were found almost on the plane through $y=0 \cdot 25$, and hence there were no spurious duplicates for these atoms. A structure factor calculation, with all the atoms included, gave an $R$ factor of $27 \%$. Four cycles of full-matrix least-square refinement were carried out on a CDC 3600 computer, using the program of Gantzel, Sparks and Trueblood, which reduced the $R$ factor to $12.5 \%$. At this stage, 50 independent reflexions measured from the cross layer data were included with the three-dimensional reflexions after correlation by the method of Rollett \& Sparks (1960). An overall scale factor was employed and the weighting scheme was that of Cruickshank et al. (1961), given by $w=1 /\left[A+\left|F_{o}\right|+C\left|F_{o}\right|^{2}\right]$ where the constants $A$ and $C$ were set values equal to 10.0 and 0.06 respectively. The $R$ factor dropped to $12.3 \%$ after two cycles of refinement.

At this stage, a difference Fourier synthesis was computed for the location of the hydrogen atoms in the structure. All fourteen hydrogen atom positions were located from the difference Fourier 


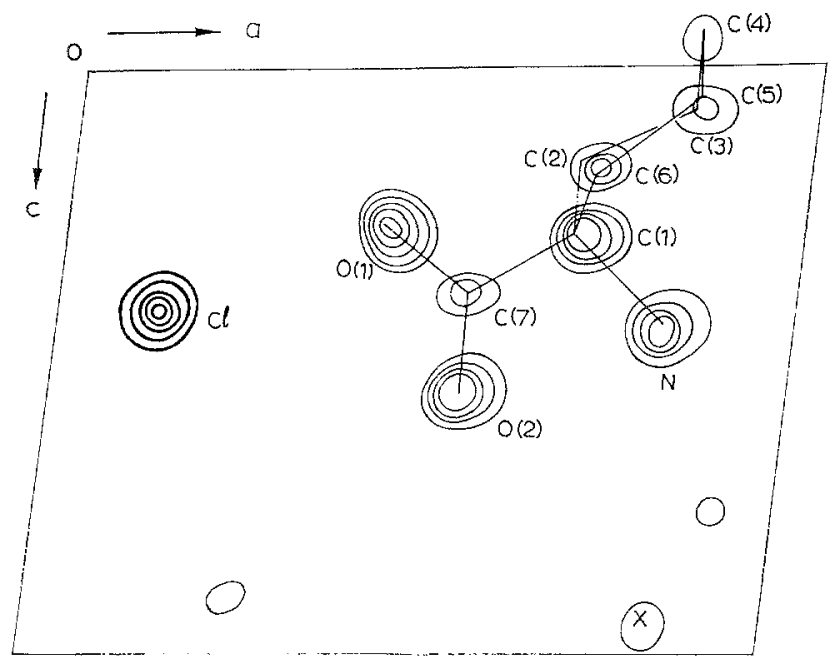

Fig. 1. Composite diagram of the beta synthesis. Contours are drawn at intervals of 2 e $\AA^{-3}$ starting from $5 \mathrm{e} \AA^{-3}$. At chlorine, they are at intervals of $5 \mathrm{e} \AA^{-3}$ starting from $5 \mathrm{e} \AA^{-3}$.

map, a composite diagram of which is given in Fig. 2. Hydrogen atoms were included in the structure factor calculation for further cycles of refinement but were not themselves refined; these hydrogen atoms were given an average temperature factor of $2.5 \AA^{2}$. Two further cycles of refinement with

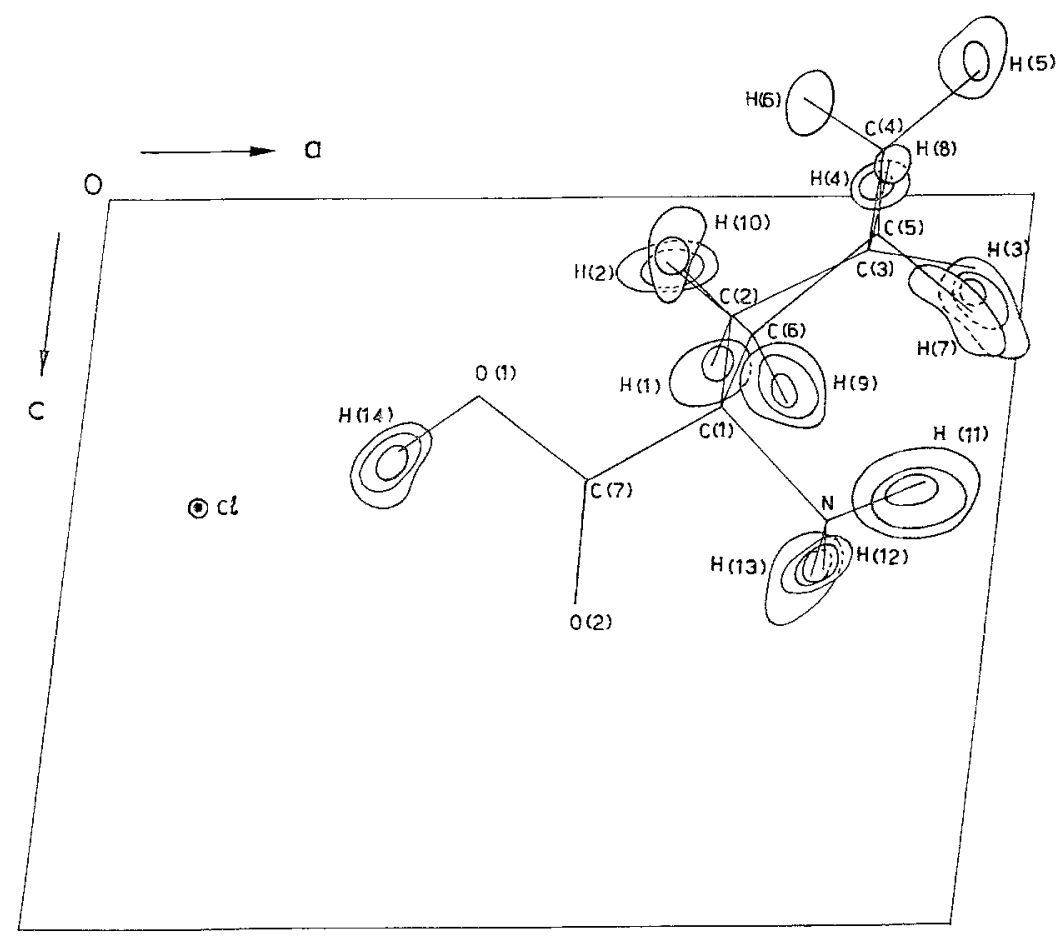

Fig. 2. Composite diagram of the difference Fourier synthesis indicating the hydrogen positions. Contours are drawn at intervals of $0.1 \mathrm{e} \AA^{-3}$, starting from $0.2 \mathrm{e} \AA^{-3}$. 
Table 1. Atomic coordinates and thermal parameters

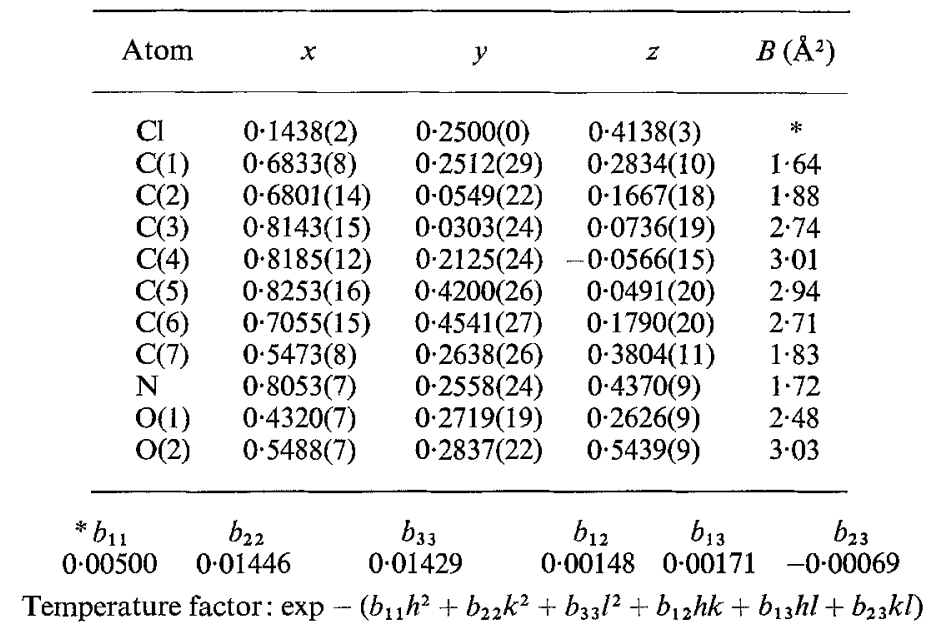

a $\Delta f^{\prime}$ correction of 0.3 due to anomalous dispersion for chlorine $\left(\mathrm{Cl}^{-}\right)$and including also an anisotropic temperature factor for the chlorine atoms reduced the $R$ factor to $10.85 \%$. Refinements which were carried out with the $\Delta f^{\prime \prime}$ correction for chlorine equal to +0.7 and -0.7 gave $R$ factors of 10.83 and $10.85 \%$ respectively. Since the difference in $R$ is not significant, a conclusion regarding the absolute configuration could not be definite and only the results with $\Delta f^{\prime \prime}=0$ are given here. The shifts in the positional parameters in the last cycle of refinement were less than one tenth of their respective standard deviations. The coordinates of the atoms from the last cycle of refinement are listed in Table 1 and the coordinates of the hydrogen atoms, obtained from the difference Fourier map, are given in Table 2.

Table 2. Coordinates of hydrogen atoms from the difference Fourier map

\begin{tabular}{lrrrl}
\hline Atom & $x$ & \multicolumn{1}{c}{$y$} & \multicolumn{1}{c}{$z$} & Bonded to \\
& & & & \\
\hline $\mathrm{H}(1)$ & 0.667 & -0.078 & 0.233 & $\mathrm{C}(2)$ \\
$\mathrm{H}(2)$ & 0.600 & 0.056 & 0.072 & $\mathrm{C}(2)$ \\
$\mathrm{H}(3)$ & 0.933 & 0.042 & 0.133 & $\mathrm{C}(3)$ \\
$\mathrm{H}(4)$ & 0.828 & -0.125 & 0.000 & $\mathrm{C}(3)$ \\
$\mathrm{H}(5)$ & 0.911 & 0.222 & -0.167 & $\mathrm{C}(4)$ \\
$\mathrm{H}(6)$ & 0.722 & 0.214 & -0.139 & $\mathrm{C}(4)$ \\
$\mathrm{H}(7)$ & 0.917 & 0.417 & 0.133 & $\mathrm{C}(5)$ \\
$\mathrm{H}(8)$ & 0.819 & 0.550 & -0.050 & $\mathrm{C}(5)$ \\
$\mathrm{H}(9)$ & 0.750 & 0.567 & 0.278 & $\mathrm{C}(6)$ \\
$\mathrm{H}(10)$ & 0.611 & 0.500 & 0.072 & $\mathrm{C}(6)$ \\
$\mathrm{H}(11)$ & 0.900 & 0.250 & 0.394 & $\mathrm{~N}$ \\
$\mathrm{H}(12)$ & 0.806 & 0.389 & 0.489 & $\mathrm{~N}$ \\
$\mathrm{H}(13)$ & 0.794 & 0.139 & 0.514 & $\mathrm{~N}$ \\
$\mathrm{H}(14)$ & 0.300 & 0.250 & 0.319 & $\mathrm{O}(1)$ \\
\hline
\end{tabular}

\section{Discussion of the structure}

Intramolecular features. Bond lengths and bond angles are listed in Table 3 . The average standard deviations of the $\mathrm{C}-\mathrm{C}, \mathrm{C}-\mathrm{N}$ and $\mathrm{C}-\mathrm{O}$ bonds are $0.019,0.015$ and $0.014 \AA$ respectively. The bond 
Table 3. Bond lengths and bond angles and their standard deviations

\begin{tabular}{llll}
\hline \multicolumn{2}{c}{ Bond length } & \multicolumn{3}{c}{ Bond angles } \\
\hline $\mathrm{C}(1)-\mathrm{C}(2)$ & $1 \cdot 523(17) \AA$ & $\mathrm{C}(1)-\mathrm{C}(2)-\mathrm{C}(3)$ & $112 \cdot 2(1 \cdot 3)^{\circ}$ \\
$\mathrm{C}(2)-\mathrm{C}(3)$ & $1 \cdot 505(20)$ & $\mathrm{C}(2)-\mathrm{C}(3)-\mathrm{C}(4)$ & $106 \cdot 7(1 \cdot 5)$ \\
$\mathrm{C}(3)-\mathrm{C}(4)$ & $1 \cdot 511(19)$ & $\mathrm{C}(3)-\mathrm{C}(4)-\mathrm{C}(5)$ & $110 \cdot 5(1 \cdot 3)$ \\
$\mathrm{C}(4)-\mathrm{C}(5)$ & $1 \cdot 535(20)$ & $\mathrm{C}(4)-\mathrm{C}(5)-\mathrm{C}(6)$ & $115 \cdot 8(1 \cdot 5)$ \\
$\mathrm{C}(5)-\mathrm{C}(6)$ & $1 \cdot 569(22)$ & $\mathrm{C}(5)-\mathrm{C}(6)-\mathrm{C}(1)$ & $109 \cdot 5(1 \cdot 5)$ \\
$\mathrm{C}(1)-\mathrm{C}(6)$ & $1 \cdot 536(19)$ & $\mathrm{C}(6)-\mathrm{C}(1)-\mathrm{C}(2)$ & $114 \cdot 1(1 \cdot 2)$ \\
$\mathrm{C}(1)-\mathrm{C}(7)$ & $1 \cdot 530(19)$ & $\mathrm{C}(6)-\mathrm{C}(1)-\mathrm{C}(7)$ & $110 \cdot 8(1 \cdot 1)$ \\
$\mathrm{C}(1)-\mathrm{N}$ & $1 \cdot 527(15)$ & $\mathrm{C}(2)-\mathrm{C}(1)-\mathrm{C}(7)$ & $110 \cdot 0(1 \cdot 2)$ \\
$\mathrm{C}(7)-\mathrm{O}(1)$ & $1 \cdot 317(14)$ & $\mathrm{C}(2)-\mathrm{C}(1)-\mathrm{N}$ & $114 \cdot 0(1 \cdot 1)$ \\
$\mathrm{C}(7)-\mathrm{O}(2)$ & $1 \cdot 219(14)$ & $\mathrm{C}(6)-\mathrm{C}(1)-\mathrm{N}$ & $103 \cdot 2(1 \cdot 2)$ \\
& & $\mathrm{C}(7)-\mathrm{C}(1)-\mathrm{N}$ & $104 \cdot 3(1 \cdot 1)$ \\
& & $\mathrm{C}(1)-\mathrm{C}(7)-\mathrm{O}(1)$ & $111 \cdot 0(1 \cdot 1)$ \\
& & $\mathrm{C}(1)-\mathrm{C}(7)-\mathrm{O}(2)$ & $122 \cdot 3(1 \cdot 2)$ \\
& & $\mathrm{O}(1)-\mathrm{C}(7)-\mathrm{O}(2)$ & $125 \cdot 8(1 \cdot 2)$ \\
\hline
\end{tabular}

distances agree fairly well with the standard values found in the literature and are within the limits imposed by the accuracy of the present analysis. The average $C-C$ bond length of $1.530 \AA$ in the cyclohexane ring agrees well with $1.533 \AA$, which is the average $\mathrm{C}-\mathrm{C}$ bond length observed in $n$-alkanes (Bartell and Kohl, 1963). The average bond angle of $111.4^{\circ}$ for the cyclohexane ring is larger than the tetrahedral angle and agrees well with the theoretically predicted angle of $111.5^{\circ}$ for a cyclohexane pure chair conformation (Bixon \& Lifson, 1967). However, it is to be mentioned that two of the $\mathrm{C}-\mathrm{C}-\mathrm{C}$ bond angles of the cyclohexane ring, namely $\mathrm{C}(2)-\mathrm{C}(3)-\mathrm{C}(4)\left(=106.7^{\circ}\right)$ and $\mathrm{C}(4)-\mathrm{C}(5)-\mathrm{C}(6)\left(=115 \cdot 8^{\circ}\right)$, show somewhat larger deviations from the expected angle but fall just within the $3 \sigma$ level and therefore are not significant. As mentioned earlier, the hydrogen atoms were located from the difference Fourier map and their positions were not refined; hence, a discussion of the bond distances involving these atoms is not worthwhile. However, we give here the mean $\mathrm{C}-\mathrm{H}$ and $\mathrm{N}-\mathrm{H}$ bond lengths found in the structure, which are 1.09 and $0.95 \AA$ respectively. The bond lengths and angles involving these hydrogen atoms are listed in Table 4.

The carboxyl group in this structure remains as a pure $-\mathrm{CO}_{2} \mathrm{H}$ group. The amino nitrogen atom is protonated $\left(\mathrm{NH}_{3}{ }^{+}\right)$with the hydrogen atom from hydrogen chloride. As found in structures of amino acids, the carboxyl group of atoms $C(7), O(1), O(2)$ and $C(1)$ are planar. The equation of the least-squares plane passing through these atoms is given by $0.056 X+0.995 Y+0.080 Z=2.122$, where $X, Y$ and $Z$ are coordinates in $\AA$ parallel to $a, b$ and $c^{*}$ respectively. The deviations of the atoms from the least-squares plane are given in Table 5. The amino nitrogen atom deviates from this plane by $0.17 \AA$. The $\mathrm{C}(1)-\mathrm{N}$ distance of $1.527 \AA$ is slightly larger than the average value of $1.487 \AA$ for the C-N distance observed in amino acids (Marsh \& Donohue, 1967). A similar feature is consistently observed in the structure of other analogues of 1-aminocycloalkane carboxylic acids. The C(1)-N distance is $1.544 \AA$ in the structure of 1-amino cycloheptane carboxylic acid hydrobromide monohydrate (Chacko et al. 1971), 1.542 $\AA$ in the case of 1-aminocyclooctane carboxylic acid hydrobromide (Srikrishnan et al. 1971) and 1.51 $\AA$ in the structure of 1-aminocyclopentane carboxylic acid hydrobromide (Chandrasekharan et al. 1967). A method of describing the conformation of the carboxyl group has been worked out in this laboratory (Ramachandran and Lakshminarayanan, 1966). The notation followed is that of Edsall et al. (1966). Starting from C(1) and looking down $\mathrm{C}(1)-\mathrm{C}(7)$ bond, the clockwise rotations of the $\mathrm{C}-\mathrm{O}$ bonds from the position cis to $\mathrm{C}(1)-\mathrm{N}$ measure the $\Psi_{1}$ and $\Psi_{2}$ angles of the carboxyl group. Since the carboxyl group is essentially planar $\left|\Psi_{1}-\Psi_{2}\right| \approx 180^{\circ}$. In this structure the values of $\Psi_{1}$ and $\Psi_{2}$ are $168^{\circ}$ and $347^{\circ}$ respectively, in conformity with the observation of Lakshminarayanan et al. 1967. Other features that have been 
K. K. CHACKO et al.

Table 4. Bond lengths and bond angles involving hydrogen atoms

\begin{tabular}{|c|c|c|c|}
\hline \multicolumn{2}{|c|}{ Bond length } & \multicolumn{2}{|l|}{ Bond angle } \\
\hline $\mathrm{C}(2)-\mathrm{H}(1)$ & $1.00 \AA$ & $C(1)-C(2)-H(1)$ & $115^{\circ}$ \\
\hline $\mathrm{C}(2)-\mathrm{H}(2)$ & 0.97 & $\mathrm{C}(3) \quad \mathrm{C}(2)-\mathrm{H}(1)$ & 107 \\
\hline $\mathrm{C}(3)-\mathrm{H}(3)$ & $1 \cdot 16$ & $\mathrm{C}(1)-\mathrm{C}(2)-\mathrm{H}(2)$ & 112 \\
\hline $\mathrm{C}(3)-\mathrm{H}(4)$ & $1 \cdot 15$ & $\mathrm{C}(3)-\mathrm{C}(2)-\mathrm{H}(2)$ & 107 \\
\hline $\mathrm{C}(4)-\mathrm{H}(5)$ & $1 \cdot 25$ & $\mathrm{H}(1)-\mathrm{C}(2)-\mathrm{H}(2)$ & 105 \\
\hline $\mathrm{C}(4)-\mathrm{H}(6)$ & $1 \cdot 04$ & $\mathrm{C}(2)-\mathrm{C}(3)-\mathrm{H}(3)$ & 130 \\
\hline $\mathrm{C}(5)-\mathrm{H}(7)$ & $1 \cdot 01$ & $\mathrm{C}(4)-\mathrm{C}(3)-\mathrm{H}(3)$ & 96 \\
\hline $\mathrm{C}(5)-\mathrm{H}(8)$ & $1 \cdot 11$ & $\mathrm{C}(2)-\mathrm{C}(3)-\mathrm{H}(4)$ & 117 \\
\hline $\mathrm{C}(6)-\mathrm{H}(9)$ & $1 \cdot 09$ & $\mathrm{C}(4)-\mathrm{C}(3)-\mathrm{H}(4)$ & 111 \\
\hline $\mathrm{C}(6)-\mathrm{H}(10)$ & $1 \cdot 16$ & $\mathrm{H}(3)-\mathrm{C}(3)-\mathrm{H}(4)$ & 95 \\
\hline $\mathrm{N}-\mathrm{H}(11)$ & 0.97 & $\mathrm{C}(3)-\mathrm{C}(4)-\mathrm{H}(5)$ & 121 \\
\hline $\mathrm{N}-\mathrm{H}(12)$ & 0.94 & $C(5)-C(4)-H(5)$ & 107 \\
\hline $\mathrm{N}-\mathrm{H}(13)$ & 0.95 & $C(3)-C(4)-H(6)$ & 107 \\
\hline \multirow[t]{16}{*}{$\mathrm{O}(1)-\mathrm{H}(14)$} & $0 \cdot 85$ & $C(5)-C(4)-H(6)$ & 106 \\
\hline & & $\mathrm{H}(5)-\mathrm{C}(4)-\mathrm{H}(6)$ & 104 \\
\hline & & $\mathrm{C}(4)-\mathrm{C}(5)-\mathrm{H}(7)$ & 107 \\
\hline & & $C(6)-C(5)-H(7)$ & 104 \\
\hline & & $\mathrm{C}(4)-\mathrm{C}(5)-\mathrm{H}(8)$ & 108 \\
\hline & & $C(6)-C(5)-H(8)$ & 108 \\
\hline & & $\mathrm{H}(7)-\mathrm{C}(5)-\mathrm{H}(8)$ & 114 \\
\hline & & $\mathrm{C}(5)-\mathrm{C}(6)-\mathrm{H}(9)$ & 105 \\
\hline & & $\mathrm{C}(1)-\mathrm{C}(6)-\mathrm{H}(9)$ & 107 \\
\hline & & $\mathrm{C}(5)-\mathrm{C}(6)-\mathrm{H}(10)$ & 99 \\
\hline & & $\mathrm{C}(1)-\mathrm{C}(6)-\mathrm{H}(10)$ & 115 \\
\hline & & $H(9)-C(6)-H(10)$ & 120 \\
\hline & & $\mathrm{C}(1)-\mathrm{N}-\mathrm{H}(11)$ & 113 \\
\hline & & $\mathrm{C}(1)-\mathrm{N}-\mathrm{H}(12)$ & 107 \\
\hline & & $\mathrm{C}(1)-\mathrm{N}-\mathrm{H}(13)$ & 108 \\
\hline & & $\mathrm{C}(7)-\mathrm{O}(1)-\mathrm{H}(14)$ & 108 \\
\hline
\end{tabular}

observed in the structure of amino acids are found to exist also in this structure. The shorter $\mathrm{C}-\mathrm{O}$ bond, $\mathrm{C}(7)-\mathrm{O}(2)$, is $c i$ s to the amino nitrogen atom about the $\mathrm{C}(1)-\mathrm{C}(7)$ bond. Correspondingly, the angle $\mathrm{C}(1)-\mathrm{C}(7)-\mathrm{O}(2)\left(122 \cdot 3^{\circ}\right)$ is larger than the angle $\mathrm{C}(1)-\mathrm{C}(7)-\mathrm{O}(1)\left(111 \cdot 0^{\circ}\right)$.

The cyclohexane ring in this structure exists in the chair conformation, which is the energetically stable conformation according to the theoretical calculations on the conformation of cyclohexane (Bixon \& Lifson, 1967; Hendrickson, 1967). The equation of the least-squares plane passing through

Table 5. Least-squares plane for the carboxylgroup and the ring carbon atoms

\begin{tabular}{cccc}
\hline $\begin{array}{c}\text { Plane through } \\
\mathrm{C}(1), \mathrm{C}(7), \mathrm{O}(1), \mathrm{O}(2)\end{array}$ & $\begin{array}{c}\text { Plane through } \\
\mathrm{C}(2), \mathrm{C}(3), \mathrm{C}(5), \mathrm{C}(6)\end{array}$ \\
\hline Atom & Deviation & Atom & Deviation \\
\hline & & & \\
$\mathrm{C}(1)$ & $-0.012 \AA$ & $\mathrm{C}(2)$ & $-0.082 \AA$ \\
$\mathrm{C}(7)$ & 0.051 & $\mathrm{C}(3)$ & 0.078 \\
$\mathrm{O}(1)$ & -0.022 & $\mathrm{C}(5)$ & -0.062 \\
$\mathrm{O}(2)$ & -0.019 & $\mathrm{C}(6)$ & 0.062 \\
$\mathrm{~N}$ & 0.17 & $\mathrm{C}(1)$ & 0.57 \\
& & $\mathrm{C}(4)$ & -0.67 \\
\hline
\end{tabular}


Table 6. Comparison of torsion angles of the cyclohexane ring with that of cyclohexane chair conformation from theoretical calculations

\begin{tabular}{cccc}
\hline Torsion angle & Present study & $\begin{array}{c}\text { Bixon and } \\
\text { Lifson (1967) }\end{array}$ & $\begin{array}{c}\text { Hendrickson } \\
(1967)\end{array}$ \\
\hline $\mathrm{C}(1)-\mathrm{C}(2)-\mathrm{C}(3)-\mathrm{C}(4)$ & $-63 \cdot 4(1 \cdot 4)^{\circ}$ & $-54 \cdot 7^{\circ}$ & $-54 \cdot 4^{\circ}$ \\
$\mathrm{C}(2)-\mathrm{C}(3)-\mathrm{C}(4)-\mathrm{C}(5)$ & $61 \cdot 4(1 \cdot 4)$ & $54 \cdot 7$ & $54 \cdot 4$ \\
$\mathrm{C}(3)-\mathrm{C}(4)-\mathrm{C}(5)-\mathrm{C}(6)$ & $-53 \cdot 7(1 \cdot 6)$ & $-54 \cdot 7$ & $-54 \cdot 4$ \\
$\mathrm{C}(4)-\mathrm{C}(5)-\mathrm{C}(6)-\mathrm{C}(1)$ & $43 \cdot 0(1 \cdot 6)$ & $54 \cdot 7$ & $54 \cdot 4$ \\
$\mathrm{C}(5)-\mathrm{C}(6)-\mathrm{C}(1)-\mathrm{C}(2)$ & $-43 \cdot 4(1 \cdot 5)$ & $-54 \cdot 7$ & $-54 \cdot 4$ \\
$\mathrm{C}(6)-\mathrm{C}(1)-\mathrm{C}(2)-\mathrm{C}(3)$ & $57 \cdot 0(1 \cdot 5)$ & $54 \cdot 7$ & $54 \cdot 4$ \\
Mean absolute deviation, & $7 \cdot 0$ & & \\
taking Bixon and Lifson's & & & \\
value as standard & & & \\
\hline
\end{tabular}

the atoms $\mathrm{C}(2), \mathrm{C}(3), \mathrm{C}(5)$ and $\mathrm{C}(6)$ is given by $0.548 X-0.022 Y+0.336 Z=4.527$. The deviations of these atoms from the least-squares plane are small and are given in Table 5. The deviations of the atoms $\mathrm{C}(1)$ and $\mathrm{C}(4)$ from the plane defined above are +0.57 and $-0.67 \AA$ respectively. It may be remarked that this is an important feature of the chair conformation of cyclohexane. The theoretically expected deviation for the cylcohexane chair conformation can be shown to be $\approx 0.73 \AA$. The torsion angles around the various $\mathrm{C}-\mathrm{C}$ bonds of the cyclohexane ring and their standard deviations (from the expression given by Huber-Buser \& Dunitz, 1961) are listed in Table 6 which gives also the theoretically expected angles of Bixon \& Lifson (1967) and Hendrickson (1967) for the cyclohexane pure chair conformation. The mean absolute deviation in torsion angle from Bixon \& Lifson's value is $7^{\circ}$. Considering the mean standard deviation in torsion angle to be $1.5^{\circ}$, the above deviation in torsion angle shows that the conformation of the cyclohexane ring in this structure is that of a slightly distorted chair. A similar distortion is observed with 4,4-diphenylcyclohexanone (Lambert et al. 1969).

Intermolecular features. The structure projected down the $b$ axis is shown in Fig. 3. The protonated amino group has three hydrogen atoms available for hydrogen-bond formation, and they take part

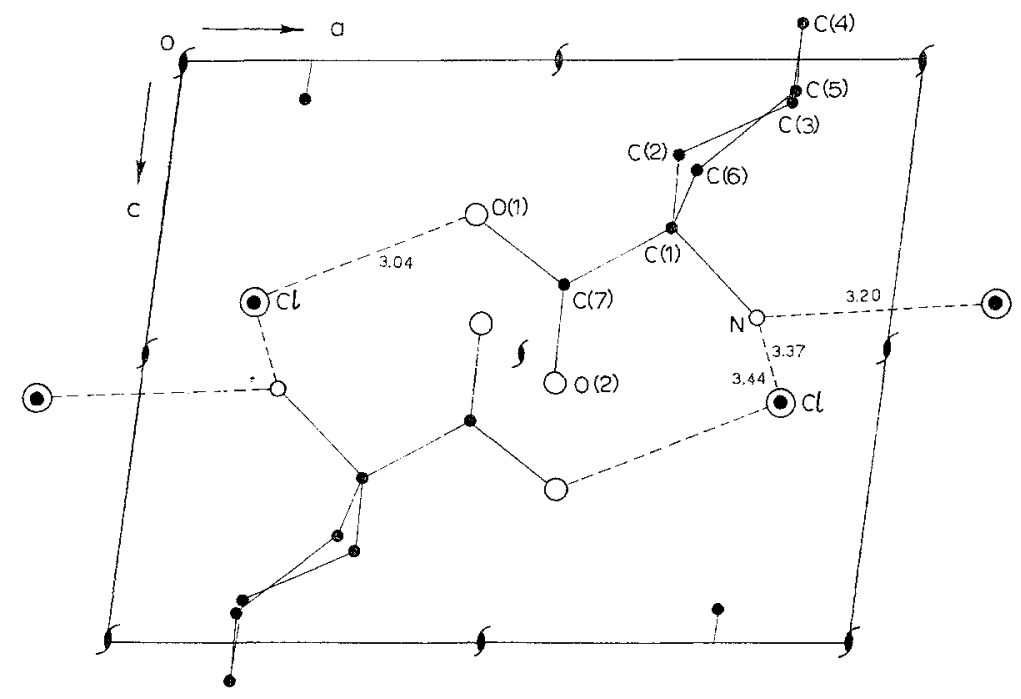

Fig. 3. View of the structure projected down $b$ axis. 


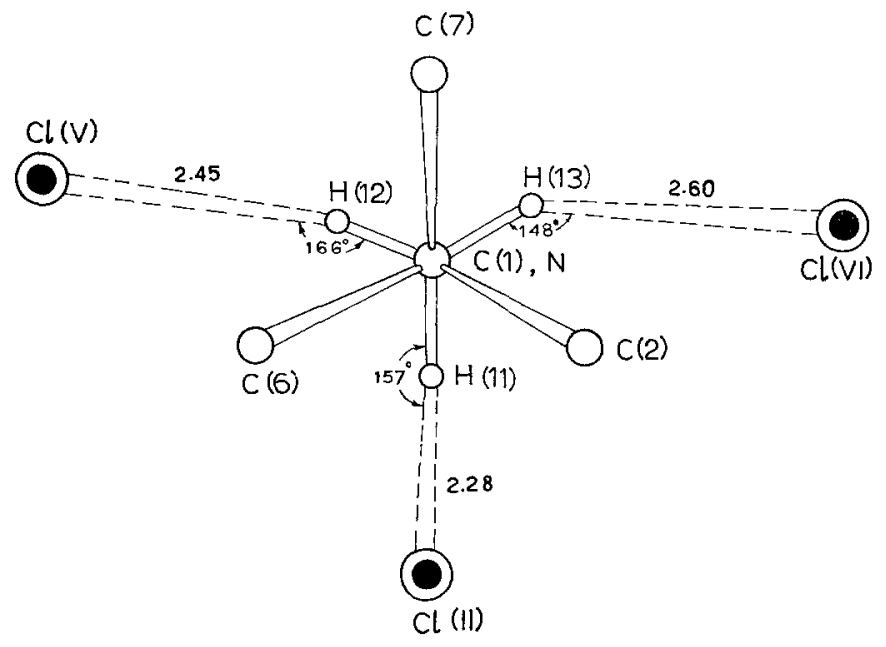

Fig. 4. Environment of amino nitrogen: projection down the $\mathrm{C}(1)-\mathrm{N}$ bond.

in hydrogen bonds with symmetry related chlorine atoms $\mathrm{Cl}(\mathrm{ii}), \mathrm{Cl}(\mathrm{v})$ and $\mathrm{Cl}(\mathrm{vi})$ at distances of $3 \cdot 20$, 3.37 and $3.44 \AA$ respectively. The corresponding distances between the hydrogen atoms and the acceptor atoms for the above bonds are $2 \cdot 28,2 \cdot 45$ and $2.60 \AA$ respectively, which are smaller than the sum of the van der Waals' radii of hydrogen ånd chlorine $(3 \cdot 0 \AA)$ and indicate strong hydrogen bonds. The projection down the $\mathrm{C}(1)-\mathrm{N}$ bond, Fig. 4 , shows the hydrogen atom positions and the

Table 7. Hydrogen bond lengths and angles

\begin{tabular}{cllll}
\hline \multicolumn{2}{c}{ Bond length } & \multicolumn{3}{c}{ Bond angle } \\
\hline $\mathrm{N}-\mathrm{H}(11) \cdots \mathrm{Cl}(\mathrm{ii})$ & $3 \cdot 20 \AA$ & $\mathrm{C}(1)-\mathrm{N} \cdots \mathrm{Cl}(\mathrm{ii})$ & $129^{\circ}$ \\
$\mathrm{H}(11) \cdots \mathrm{Cl}(\mathrm{ii})$ & $2 \cdot 28$ & $\mathrm{C}(1)-\mathrm{N} \cdots \mathrm{Cl}(\mathrm{v})$ & 109 \\
$\mathrm{~N}-\mathrm{H}(12) \cdots \mathrm{Cl}(\mathrm{v})$ & $3 \cdot 37$ & $\mathrm{C}(1)-\mathrm{N} \cdots \mathrm{Cl}(\mathrm{vi})$ & 106 \\
$\mathrm{H}(12) \cdots \mathrm{Cl}(\mathrm{v})$ & $2 \cdot 45$ & $\mathrm{~N}-\mathrm{H}(11) \cdots \mathrm{Cl}(\mathrm{ii})$ & 158 \\
$\mathrm{~N}-\mathrm{H}(13) \cdots \mathrm{Cl}(\mathrm{vi})$ & $3 \cdot 44$ & $\mathrm{~N}-\mathrm{H}(12) \cdots \mathrm{Cl}(\mathrm{v})$ & 166 \\
$\mathrm{H}(13) \cdots \mathrm{Cl}(\mathrm{vi})$ & $2 \cdot 60$ & $\mathrm{~N}-\mathrm{H}(13) \cdots \mathrm{Cl}(\mathrm{vi})$ & 147 \\
$\mathrm{O}(1)-\mathrm{H}(14) \cdots \mathrm{Cl}(\mathrm{i})$ & $3 \cdot 04$ & $\mathrm{C}(7)-\mathrm{O}(1) \cdots \mathrm{Cl}(\mathrm{i})$ & 117 \\
$\mathrm{H}(14) \cdots \mathrm{Cl}(\mathrm{i})$ & $2 \cdot 21$ & $\mathrm{O}(1)-\mathrm{H}(14) \cdots \mathrm{Cl}(\mathrm{i})$ & 165 \\
\hline
\end{tabular}

Symmetry code:
(i) $x, y, z$
(ii) $1+x, y, z$
(iii) $x, 1+y, z$
(iv) $x, y, 1+z$
(v) $-x+1, \frac{1}{2}+y,-z+1$

$$
\begin{aligned}
& \text { (vi) }-x+1, \frac{1}{2}+y-1,-z+1 \\
& \text { (vii) }-x, \frac{1}{2}+y-1,-z+1 \\
& \text { (viii) }-x+1, \frac{1}{2}+y,-z \\
& \text { (ix) }-x+1, \frac{1}{2}+y-1,-z \\
& \text { (x) }-x+2, \frac{1}{2}+y-1,-z
\end{aligned}
$$

hydrogen bond directions. All hydrogen bond directions may be seen to be staggered with respect to the covalent bonds which emanate from the $\mathrm{C}(1)$ atom. The hydrogen atom on the carboxyl oxygen atom, $\mathrm{O}(1)$, forms a hydrogen bond of length $3.04 \AA$ with $\mathrm{Cl}(\mathrm{i})$. The symmetry code and the relevant hydrogen bond distances and angles are given in Table 7.

The authors wish to thank Professor G. N. Ramachandran for his keen interest. The full-matrix least-squares refinement program used was that of Gantzel, Sparks \& Trueblood, modified for the CDC 3600 computer by Zalkin, Lundgren, Liminga \& Braenden. Thanks are due to these individuals 


\section{STUDIES IN MOLECULAR STRUCTURE, SYMMETRY AND CONFORMATION 269}

for making available their program. Thanks are also due to the authorities of the Tata Institute of Fundamental Research, Bombay, for making available the computer facilities. This work was supported in part by Grant NB-05306 to R.Z. from the National Institute of Neurological Diseases and Stroke, National Institutes of Health.

\section{References}

Bartell, L. S. \& Kohl, D. A. (1963) J. Chem. Phys. 39, 3097.

Bixon, M. \& Lifson, S. (1967) Tetrahedron, 23, 769.

Chacko, K. K., Srinivasan, R. \& Zand, R. (1971) J. Cryst. Mol. Struct. 1, 213.

Chandrasekharan, R., Mallikarjunan, M., Godavari Chandrasekharan \& Zand, R. (1968) Curr. Sci. (India) 37,91 .

Cruickshank, D. W. J., Philling, D. E., Bujosa, A., Lovell, F. M. \& Truter, M. R. (1961) In Computing Methods and phase problem (Pergamon Press, London, p. 32).

Edsall, J. T., Flory, P. J., Kendrew, J. C., Liqouri, A. M., Nemethy, G., Ramachandran, G. N. \& Scheraga, H. A. (1966) J. Mol. Biol. 15, 399.

Hendrickson, J. B. (1967) J. Amer. Chem. Soc. 89, 7036.

Huber-Buser, E. \& Dunitz, J. D. (1961) Helv. Chem. Acta, 44, 2027.

Lakshminarayanan, A. V., Sasisekharan, V. \& Ramachandran, G. N., (1967) In Conformation of Biopolymers, ed. Ramachandran, G. N. (Academic Press, London, p. 61).

Lambert, J. B., Carhart, R. E. \& Corfield, P. W. R. (1969) J. Amer. Chem. Soc. 91, 3567.

Marsh, R. E. \& Donohue, J. (1967) Advances in Protein Chemistry, 22, 235.

Phillips, D. C. (1962), International Tables for X-ray Crystallography, Vol. III, p. 140.

Ramachandran, G. N. \& Ayyar, R. R. (1963) In Advanced methods in Crystallography, ed. Ramachandran, G. N. (Academic Press, London, p. 25).

Ramachandran, G. N. \& Lakshminarayanan, A. V. (1966), Biopolymers, 4, 495.

Ramachandran, G. N. \& Raman, S. (1959), Acta Crystallogr. 12, 957.

Rollett, J. S. \& Sparks, R. A. (1960), Acta Crystallogr. 13, 272.

Srikrishnan, T., Srinivasan, R. \& Zand, R. (1971) J. Cryst. Mol. Struct., 1, 199.

National Lending Library Supplementary Publication No. 60021 contains 1 page of structure factor tables on 1 microfiche. 